\title{
Human and long-tailed macaque conflict in Central Java, Indonesia
}

\author{
Wahyuni Fitria*, Azis Nur Bambang, Jafron Wasiq Hidayat \\ Master Program of Environmental Sciences, School of Post-Graduate, Diponegoro University, \\ Semarang - Indonesia
}

\begin{abstract}
Long-tailed macaques are highly adaptive in various types of habitats. Their behaviour who are accustomed to living in groups with specific activities greatly affects the home range in getting food. They have ecological and cultural values for a particular community; unfortunately, it was well known as an agricultural crop pest. Quality of the habitat to be one determinant factor of macaques disruptions. The purposes of the study are to understand the conditions of conflict humans and macaques in Central Java that used as a reference in determining solutions. Data analyzed descriptively from various reports and research findings. The data collected identified from 2011 to 2019. Disturbance of long-tailed macaque in Central Java occurs at least 15 regencies with the population reaching thousands of individuals of damage to crops and even enter settlements. The macaque's behaviour that is considered detrimental causes conflicts with humans which at the end, creating various handling efforts ranging from expulsion to hunting. Some research findings show that people's perceptions of wild animals will affect efforts to resolve or mitigate the problem of human conflict with wildlife and negative attitudes can cause adverse effects for conservation efforts.
\end{abstract}

Keywords. Macaques, conflict, human, perceptions, efforts

\section{Introduction}

Indonesia is a country with a high diversity of flora and fauna. The fauna group which is quite evenly distributed and has a high population, namely long-tailed macaques (Macaca fascicularis). Long-tailed macaques are wild animals, which until now have not been registered in Permen LHK No. P.106/2018 as a protected animal. In the International Union for Conservation of Nature Resources (IUCN), long-tailed macaques are classified as Least Concern (LC) and included in appendix II of CITES (Convention of International Trade Endangered Species of Flora and Fauna), so that they can still be traded in specific quotas [1]. Long-tailed macaques become one of the population groups in the forest whose existence is also an important agent in the regeneration of tropical forests. In their habitat, the macaques play an ecological role in distributing forest seeds [2]. The distribution of

\footnotetext{
*Corresponding author: wahyuni.fitria@gmail.com
} 
long-tailed macaque populations in Indonesia is quite extensive, ranging from west to east of Indonesia, from Sumatra to Papua. It is because long-tailed macaques can adapt to various types of habitat [3]. This macaque has a high value for human life both in terms of ecology, biomedicine, recreation, and aesthetics [4].

The behaviour of wild animals, including long-tailed macaques naturally, does not cause disturbances when living in their natural habitat and away from people's lives. Behaviour Changes of macaques cause of conflicts with humans are very likely to occur due to the movement of macaques to areas close to the community [5]. Based on the Minister of Forestry Regulation Number P.48/Menhut-II/2008, conflicts between humans and wildlife occur as a result of negative interactions both directly and indirectly between humans and wildlife. Several factors that can trigger conflicts include the conversion of forests into settlement and farming areas, which can disturb the lives of wildlife will also disrupt their home range. Besides natural feed sources for overexploited wildlife also force wildlife, including long-tailed macaques to look for food outside their habitat [6]. Its nature also conditions it in feeding status, which is frugivorous or fruit eater, but too often to be opportunistic omnivores that can adapt to other types of food available such as young leaves, insects, plant shoots, etc. [7].

\section{Literature Study}

\subsection{Morphology and behaviour of long-tail macaque}

Long-tailed macaques have several local names in various regions in Indonesia, including kethek (Java), kunyuk (Sunda), karau (Sumatra), bedes (Tengger), motak (Madura), warik (Kalimantan), belo (Timor) and cigaq (Minangkabau). Long-tailed macaques are species of macaque whose tail is close to the length of its body with its hind legs longer than its front legs. With a body length of 38-64 cm, tail length reaches $40-65 \mathrm{~cm}$. Adult long-tailed macaques have a bodyweight of 3-8 $\mathrm{kg}$ (3.5-8 $\mathrm{kg}$ for bush individuals and $3 \mathrm{~kg}$ for females) with hair colour varying from grey to brown with ventral in white [2]. Long-tailed macaques also have food pouches on the cheeks to store food temporarily and have sitting cushions attached to the sitting bones [8]. Gray on the cheeks is found on the individual, while young animals usually own the high crest on the head. His nose is flat with the tip of the nose narrowed. This macaque has spade-shaped incisors, canines and molars for chewing food. The ability of long-tailed macaques to walk and run using their front and back legs strongly supports their ability to adapt in various types of habitat [9].

Animal behaviour is a variety of activities carried out because of the stimulus both from the inside (internal) and the reaction to external influences (external) in the form of interactions with other animals or the environment. Examples of Internal influences such as hunger, fear and the urge to do reproductive behaviour. Furthermore, external influences include disturbed habitats, the impact of weather and the presence of predators [10]. Nonsocial activities which include eating, moving, and inactive behaviour are some of the longtailed macaque activities besides social affiliation, namely grooming and playing and social agonism [9]. It also affects the home range to obtain food and drink sources [11]. Longtailed macaque behaviour that too often occurs aggressively behaviour that generally occurs in adult male and pre-adult males. The causes of macaque aggression are various among them to fight over food sources, mates, hierarchy and to maintain power from other groups of attack [10]. This behaviour often leads to fights and attacks. Long-tailed macaques are diurnal animals that actively search for food in the morning and evening, and most of their activities carried out in the tree (arboreal). 


\subsection{Habitat and home range long-tailed macaque}

Like a wild animal that has high adaptability, long-tailed macaques can live in primary and secondary forests ranging from lowlands to highlands $\geq 1000$ meters above sea level, namely in secondary growth areas, resident plantations, and even around settlements [4]. Long-tailed macaques are non-human primates that are very adaptive so they can spread in various types of habitats and live in a colony in specific populations and formed social interactions with other individuals in the group [3].

An area that can provide food, drink, shelter, rest, and perform reproductive activities will be visited by wildlife regularly. This region is called the home range. Unlike the territory that will be guarded by aggressive behaviour, the home range is not maintained from the entry of other species. Generally, the home range is wider than the territory. The variety of home ranges varies depending on the potential for environmental resources, the worse the condition, the wider the range [12]. Home range of long-tailed macaque reach 10-80 ha in primary forests, while in mangrove forests reach 125 ha [2]. Mampioper (2006) said unlike other types of mammals, and long-tailed macaques can peel fruits and seeds with their hands so that they can exploit many types of food. This provides ecological benefits because it can expand its home range both in its natural habitat and in new habitat so that long-tailed macaques become invasive animals [13].

\subsection{Interaction of long-tailed macaque with humans}

Long-tailed macaques have a history of living near human activities and human settlements, and they adapt well to succeed reproductively in human-influenced environments. For example, long-tailed macaques tend to prefer forest edge habitats and areas that are altered by human activities because they are often found along the edges of the environment planted by humans. They also adjust well to human-based food resources, such as junk and food, have given directly to them [14].

Long-tailed macaque is a type of animal that can follow the development of human civilization and has a high enough value both ecologically, aesthetically, recreation, biomedical, and commercial. Long-tailed macaques have excellent abilities in interactions with humans and can even be supported in community income when macaque habitat becomes a tourist destination. Even primate education has a unique chance to be developed if the aggressive behaviour of macaques can be controlled [5].

The long-tailed macaque's relationship with humans is close, diverse, ambivalent, and in some cases, problematic. Some of the many phenomena that occur now ranging from habitat loss, habitat fragmentation, annihilation and other population control measures intended to reduce conflict with humans, as well as capture for use in biomedical research can cause extinction [14]. The problems associated with long-tailed apes that interact with humans are genuinely an international environmental dilemma, affecting sixteen countries and millions of people. The extensive overlap between humans and apes in Southeast Asia is mostly driven by extensive anthropogenic development and rapid habitat modification [14].

\section{Methodology}

This paper is a literature study by compiling scientific literary in the range $2000-2019$ in the form of official reports and mass media relating to the conflict of long-tailed macaques with humans. The results of this literature review can be used as material for consideration to 
identify a specific location that suite / non-suite to management policy to reduce the risk of long-tailed macaque disturbance.

\section{Discussion}

Long-tailed macaques are wildlife species that have a very high level of adaptation and supported by body morphology that allows agile and fast movements. These make it easy to expand into settlements and fields to find sources of food and drink. In Central Java, longtailed macaque disturbance occurs in several regencies, especially if there is a forest area close to the population because one of the characteristics of long-tailed macaques is that they can live side by side and interact with humans. Based on community reports to the Central Java Regional Forestry Agency and the Office of the Environment and Forestry of Central Java Province, in the past five years, at least macaque disturbance occurred in 15 regencies/cities with populations reaching tens to thousands of individuals as presented in Table 1 and Table 2 below.

Table 1. Inventory of long-tailed macaque disturbance based on community reports to The Natural Resources Conservation Agency of Central Java

\begin{tabular}{|c|c|c|}
\hline Location & Population & Impact \\
\hline \multicolumn{3}{|l|}{ Temanggung Regency } \\
\hline Ds. Gandulan, Kec. Kaloran & \pm 150 & $\begin{array}{l}\text { damage food crops and enter } \\
\text { settlements }\end{array}$ \\
\hline $\begin{array}{l}\text { Dsn. Jetisan, Ds Walitelo, Kec. } \\
\text { Temanggung }\end{array}$ & \pm 12 & damaging crops \\
\hline $\begin{array}{l}\text { Ds. Pakis Kulon, Ds Pakis, Kec. } \\
\text { Pakis }\end{array}$ & $\pm 30-40$ & $\begin{array}{l}\text { damage the corn, cassava, and nuts } \\
\text { around Gunung Balak Kec. Pakis }\end{array}$ \\
\hline Ds. Legoksari, Kec. Tlogomulyo & 2 groups & damage food crops \\
\hline \multicolumn{3}{|l|}{ Magelang City } \\
\hline Mount Tidar & \pm 400 & $\begin{array}{l}\text { disruption in the tourist destination of } \\
\text { Mount Tidar }\end{array}$ \\
\hline \multicolumn{3}{|l|}{ Semarang Regency } \\
\hline Ds. Sepakung, Kec. Banyubiru & 6 groups & $\begin{array}{l}\text { damages the farms of cassava, } \\
\text { eggplants, corn, tomatoes, cabbage, } \\
\text { beans, leeks }\end{array}$ \\
\hline \multicolumn{3}{|l|}{ Boyolali Regency } \\
\hline Kec. Kemusu dan Karanggede & 1 & 14 people were bitten \\
\hline \multicolumn{3}{|l|}{ Karanganyar Regency } \\
\hline TWA Grojogan Sewu & unknown amount & 2 bite attacks, disturbing visitors \\
\hline \multicolumn{3}{|l|}{ Magelang Regency } \\
\hline $\begin{array}{l}\text { Stalang, Sejarak, Serno Kec. } \\
\text { Pakis }\end{array}$ & \pm 300 & $\begin{array}{l}\text { damaging crops of residents around } \\
\text { Gunung Balak }\end{array}$ \\
\hline $\begin{array}{l}\text { Wonogiri Regency } \\
\text { Ds. Bukurejo, Ds, Semin, Ds. } \\
\text { Ngadipiro, Kec. Nguntoroadi }\end{array}$ & unknown amount & $\begin{array}{l}\text { damaging crops and entering } \\
\text { settlements }\end{array}$ \\
\hline Ds. Setrorejo, Kec. Baturetno & unknown amount & $\begin{array}{l}\text { damaging crops and entering } \\
\text { settlements }\end{array}$ \\
\hline Ds. Pucung, Kec. Kismantoro & \pm 80 & damaging crops \\
\hline
\end{tabular}


The data above shows the long-tailed macaque disturbance obtained from public reports. Long-tailed macaques mostly damage crops in the form of cassava, corn, tomatoes, bananas, etc. Monkeys also enter settlements so that its existence is quite disturbing for the community. The population number mentioned above is an estimate based on information received by the The Natural Resources Conservation Agency of Central Java, but an inventory of the actual population has not been carried out. From the report, it has been followed up by checking directly into the field. Mitigation efforts have been carried out, namely by securing MPTS (Multy Purpose Tree Species) plants to feed macaques, blocking off firecrackers, installing nets for traps, and even catching them which are then handed over to the health centre. Besides, coordination carried out with related parties, so the steps can be taken that do not endanger the community or the animals themselves.

Table 2. Inventory of long-tailed macaque disturbance based on community reports to Department of Environment and Forestry of Central Java

\begin{tabular}{|c|c|c|c|c|}
\hline \multirow{2}{*}{ Location } & \multirow{2}{*}{ Population } & \multicolumn{2}{|c|}{ Disturbed area } & \multirow{2}{*}{$\begin{array}{l}\text { Dry } \\
\text { Land }\end{array}$} \\
\hline & & Settlements & Agricultural & \\
\hline \multicolumn{5}{|l|}{ Blora Regency } \\
\hline $\begin{array}{l}\text { Kedungwungu village in } \\
\text { Todanan distric }\end{array}$ & 2 groups $( \pm 60)$ & & & $\mathrm{v}$ \\
\hline $\begin{array}{l}\text { Gandu and Gayam village } \\
\text { in Bogorejo district }\end{array}$ & 3 groups & & $\mathrm{v}$ & \\
\hline Pati Regency & & & & \\
\hline $\begin{array}{l}\text { Sukobubuk village in } \\
\text { Margorejo district }\end{array}$ & \pm 70 & & & $\mathrm{v}$ \\
\hline $\begin{array}{l}\text { Plukaran village in } \\
\text { Gembong district }\end{array}$ & \pm 500 & $\mathrm{v}$ & & $\mathrm{v}$ \\
\hline $\begin{array}{l}\text { Wukirsari village in } \\
\text { Tambakromo district } \\
\text { Jepara Regency }\end{array}$ & \pm 250 & & $\mathrm{v}$ & \\
\hline $\begin{array}{l}\text { Tempur and Damarwulan } \\
\text { village in Keling district }\end{array}$ & $\pm 60-342$ & & & $\mathrm{v}$ \\
\hline $\begin{array}{l}\text { Somosari village in Batealit } \\
\text { district }\end{array}$ & \pm 1500 & & $\mathrm{v}$ & $\mathrm{v}$ \\
\hline $\begin{array}{l}\text { Bategede village in } \\
\text { Nalumsari district }\end{array}$ & \pm 1200 & & $\mathrm{v}$ & $\mathrm{v}$ \\
\hline $\begin{array}{l}\text { Bungu village in Mayong } \\
\text { district }\end{array}$ & \pm 5000 & $\mathrm{v}$ & $\mathrm{v}$ & $\mathrm{v}$ \\
\hline Kudus Regency & & & & \\
\hline $\begin{array}{l}\text { Kandangmas village in } \\
\text { Dawe district } \\
\text { Boyolali Regency }\end{array}$ & \pm 200 & & $\mathrm{v}$ & \\
\hline $\begin{array}{l}\text { Klakah, Jrakah, Suroteleng, } \\
\text { Samiran, Selo, Tarubatang, } \\
\text { Senden, and Jeruk village in } \\
\text { Selo district } \\
\text { Semarang Regency }\end{array}$ & $\pm 200-800$ & & $\mathrm{v}$ & \\
\hline $\begin{array}{l}\text { Sepakung, Wirogomo, and } \\
\text { Gedong village in } \\
\text { Banyubiru district } \\
\text { Batang Regency }\end{array}$ & $\pm 25-200$ & & & $\mathrm{v}$ \\
\hline Silurah, Sodong, and & $\pm 50-100$ & & $\mathrm{v}$ & $\mathrm{v}$ \\
\hline
\end{tabular}


Gringgingsari village in

Wonotunggal district

Timbang village in

$\pm 30$

$\mathrm{v}$

Banyuputih village

Tegalombo village in

$$
\pm 25
$$

Pecalungan district

Pekalongan Regency

Tajur, Lambur,

Kandangserang,

Wangkelan, and

Bojongkoneng village in

Kandangserang district

Brondong, Windurejo, and

Ujungnegoro village in

Kesesi district

Kutorojo, Linggoasri, and

$\mathrm{v}$

Brengkolang village in

Kajen district

Lambanggelun and Tenogo

$\mathrm{V}$

$\mathrm{V}$

village in Paninggaran

district

Sidomulyo, Timbangsari,

Wonosido, Depok,

$\pm 150-300$

V

V

Pamutuh, Bantarkulon, and

Mendolo village in

Lebakbarang district

Banyumas Regency

Cikakak village in Wangon

district

Kalisalak village in

$$
\pm 1000
$$$$
\pm 125
$$

$\pm 100-200$

$\mathrm{V}$

Tirto village in Grabag

$$
\pm 80
$$

$\mathrm{V}$

Bandongan district

$\pm 300-400$

V

V

Giritengah village in

Borobudur district

Temanggung Regency

Sunggingsari and

dozens

V

Glapansari village in

Parakan district

Batursari, Petarangan,

hundreds

V

Paponan, Kruwisan ang

Jambu village in Kledung

district

Wonogiri Regency

Batuwarno, Sendangsari,

$\pm 50-1500$

V

V

V

Tegiri, Selopuro, and 
Sumberejo village in

Batuwarno district

Belikurip village in

Baturetno district

Pulutan Wetan, Gumiwang

Lor, and Genuk Harjo

village in Wuryantoro

district

Pucung and Bugelan village

in Kismantoro district

Biting, Kepyar, and Sumber

village in Purwantoro

district

Pare, Keloran, and

Kepatihan village in

Selogiri district

Sendang, Wuryorejo,

Giripurwo, Giritirto, and

Giriwono village in

Wonogiri district

Sempukerep and Sembukan

village in Sidoharjo district

Kembang, Girimulyo, and

Balepanjang village in

Jatipurno district

Setren, Sokoboyo, Tunggur,

and Made village in

Slogohimo district

Gudangharjo, Gunturharjo,

and Paranggupito village in

Paranggupito district

Gemawang village in

Ngadirojo district

Ngadipiro village in Kec.

Nguntoronadi district

Sukoharjo Regency

Sanggang, Kamal, Gentan,

Kedungsono, Bulu, Tiyaran,

Puron village in Bulu

district

Long-tailed macaque conflict with humans tends to increase in recent years, especially after the occurrence of looting and forest fires. From table 1 and table 2 above it can be seen that the disturbance of long-tailed macaques occurs in many locations in Central Java, especially villages that are located close to the forest area. With the number of the population estimated are hundreds to thousands, the presence of macaques is a threat to communities, both to its crops and safety. In addition to damaging/eating, macaque plants can also injure with bites and even risk of transmitting disease. These primates have the potential to spread measles, influenza A and B and herpes B, and SFV (simian foamy virus) [15].

$$
\begin{aligned}
& \pm 300-500 \\
& \pm 500-1100
\end{aligned}
$$$$
\pm 100-200
$$

$$
\pm \text { 500-1500 }
$$


The data above shows that most of the macaque expansion occurred on agricultural land and dry land, and some of them also entered into settlements. In agricultural areas, they became a pest to corn, cassava, cabbage, shallots, and even tobacco shoots. It is consistent with author finding (references) that macaques are opportunistic omnivores (can adapt to various types of food). The availability of abundant food sources on cultivated land is an attraction for wildlife, including long-tailed macaques. Moreover, if the forest as a habitat for macaques around the settlement is not able to provide food, water, and comfort, forcing the macaques to go down to settlements and agricultural land to maintain their survival. According to name [16], an area will be visited by wild animals regularly if there is a supply of food, drink, and has a function as a shelter, a place to rest, and a place to reproduce- Macaques often come to settlements in the late afternoon, and most of them perched in trees. Even though most of them immediately left when they saw humans, the presence of macaques in this settlement was considered very disturbing because besides stealing food and fruits could also threaten the health and safety of residents [17].

The high frequency of long-tailed macaque disturbance lately is an indication of the declining quality of the forest ecosystem as their habitat. Uncontrolled land exchange can disrupt wildlife habitats and cause changes in macaque's daily behaviour that will attract them to use the area around settlements or fields as their habitat [17]. It can disrupt society, livestock, and damage crops, causing human conflict with long-tailed macaques to get worse.

In addition to the residential and agricultural areas, human conflicts with long-tailed macaques also often occur at tourist destinations. Central Java has several tourist destinations that are known to have many long-tailed macaques including TWA Grojogan Sewu in Karanganyar, Mount Tidar in Magelang City, and Jatibarang Reservoir in Semarang City. Macaque disturbances often report the tourist sites to visitors. The occurrence of macaque aggressiveness in tourism objects also influenced by the habits of visitors who often provide food (feeding and contact feeding) and interact nearby [18]. Other provocation behaviour from visitors who can initiate macaque aggressiveness is to show/bring food (food expose), threaten (threat). For example by taking pictures or taking pictures with the macaque, touching (direct contact), close (close contact) with a distance of $\leq 1 \mathrm{~m}$ from the macaque, eye contact (eye contact) and hitting (kicking) macaques [15]. Long-tailed macaque aggressiveness due to visitor provocation is higher than without provocation. Food is a major factor causing the high interaction of macaques with visitors.

Long-tailed macaque disturbance occurs in many regions of the world. But once human perceptions of long-tailed macaques can be different, some consider it is punished because of their unacceptable behaviour, but some others have a more tolerant view. According to Knight (2000), cultural values in the community also influence the perception of wildlife conflict and in turn, will determine the effectiveness of mitigation efforts [19]. The existence of an evolutionary relationship sometimes also makes humans respect primates, as in some regions, primates have spiritual values to be respected and worshipped. Such beliefs are usually associated with cultural rules that forbid harming or killing these animals. Differences in perception also influenced by the location where humans live, close to, or not to wildlife [20]. According to Carnover (2002), sociodemographic variables also associated with public acceptance of wildlife. For example, compared to part-time farmers, producers who depend on income on their agricultural land are often less tolerant of wildlife and tend to prefer to control their population [21].

For farmers, the perception of wildlife also influenced by psychological conditions experienced when planting and caring for their plants so that financial losses may not be the primary measure. Tolerance to the continuous damage caused by wildlife disturbance can be different for each person. Moreover, it also depends on several factors such as economic status, cultural attitudes toward certain species and the frequency and intensity of conflicts 
that occur (Mishra 1997; Nath dan Sukumar 1998; Naughton et al. 1999; Knight 2000 in [19]). Primates, including long-tailed macaques, are often regarded as agricultural pests that cause significant damage. They incur losses on cost, time and energy for farmers because they have to protect their crops, thus triggering conflict (Boulton et al., 1996; Hill, 2000; Loudon et al., 2006b; Naughton-Treves, 1997; Priston, 2005 in [20]). These conflicts tend to cause negative human perceptions of long-tailed macaques and can cause adverse effects for conservation efforts [6]. Material losses experienced continuously cause hostile and intolerant communities to protect wildlife [22]. It can be from the various efforts made by humans to anticipate or stop the disturbance starting from preventive measures by using puppets (scarecrow), using strong odours such as shrimp paste, using firecrackers to dispel macaques until hunting is done [23]. Efforts that lead to the destruction of macaques can undoubtedly have a bad influence on the balance of the ecosystem. Thus it can be said that people's perceptions or attitudes towards wildlife will affect efforts to resolve or mitigate the problem of human conflict with wildlife (Hill 2004; Dickman 2010 in [19]). It hoped that the mitigation efforts undertaken can ensure the welfare of local communities but also provide guarantees for the sustainability of the animals themselves [24].

\section{Conclusions}

Long-tailed macaque disturbances in Central Java occur in almost all of the regencies/cities. Most of the reported damage to crops that cause crop failure resulting in significant losses as well as to their aggressive behaviour to visitors. Macaques that enter the settlement also cause anxiety because, in addition to eating food, they can also be injured with a bite. Besides economic losses, the disturbance of long-tailed macaques also has the potential to cause critical land. It can happen if farmers begin to be reluctant to plant their fields because they are continuously losing money due to macaque disturbance. Efforts have been made by the community to minimize losses that are mostly in the form of short-term handling by repelling macaques that come. This step is seen as not yet showing significant results to prevent macaques from returning to the fields. On the other hand, sometimes hunting can threaten the macaque population in the future. Therefore, it is necessary to find the most effective treatment solution that can guarantee the welfare of the local community, but also pay attention to the ecological balance and ecosystem sustainability by considering internal and external factors, including the perception and participation of the community in an area.

\section{References}

1 T. Soehartono, Pelaksanaan Konvensi CITES di Indonesia (Jakarta: JICA, 2003)

2 J. Supriatna and E. Wahyono, Panduan Lapangan Primata Indonesia. (Jakarta: Yayasan Obor Indonesia, 2000).

3 Suwarno, "Studi Perilaku Harian Monyet Ekor Panjang (Macaca fascicularis) di Pulau Tinjil," in Prosiding Seminar Nasional XI Biologi, Sains, Lingkungan dan Pembelajarannya (2014)

4 J. Supriatna, "Konservasi Satwa Primata, Tinjauan Aspek Ekologi, Sosial Ekonomi, dan Medis dalam Pengembangan Ilmu Pengetahuan dan Teknologi," in Seminar Primatologi Indonesia (2000)

5 D. Djuwantoko, R. N. Utami, and W. Wiyono, "Perilaku Agresif Monyet, Macaca fascicularis (Raffles, 1821) terhadap Wisatawan di Hutan Wisata Alam Kaliurang, Yogyakarta". J. Biol. Divers., 9, 4, 301-305 (2008) 
6 B. Santoso, S. Febriani, and D. Subiantoro, "Pemetaan Konflik Monyet Ekor Panjang (Macaca fascicularis Raffles) di Desa Sepakung Kecamatan Banyubiru Regency Semarang," Indones. J. Conserv., 8, 2, 138-145 (2019)

7 K. Fakhri, B. Priyono, and M. Rahayuningsih, "Studi Awal Populasi dan Distribusi Macaca fascicularis Raffles di Cagar Alam Ulolanang," Unnes J. Life Sci., 1, 2, 119 125 (2012)

8 S. M. Sinaga, P. Utomo, S. Hadi, and N. A. Archaitra, Pemanfaatan Habitat oleh Monyet Ekor Panjang (Macaca fascicularis) di Kampus IPB Darmaga. (Bogor: Fakultas Kehutanan IPB, 2010)

9 G. H. Lee, J. P. Thom, K. L. Chu, and C. M. Crockett, "Comparing the Relative Benefits of Grooming-contact and Full-contact Pairing for Laboratory-housed Adult Female Macaca fascicularis," Appl. Anim. Behav. Sci., 137, 3-4, 157-165 (2012)

10 D. Sajuthi et al., "Macaca fascicularis : Kajian Populasi, Tingkah Laku, Status Nutrien dan Nutrisi untuk Model Penyakit," in Hewan Model Satwa Primata (Bogor: IPB Press, 2016)

11 D. P. Sari, S. Suwarno, A. Saputra, and M. Marjono, "Studi Perilaku Monyet Ekor Panjang (Macaca fascicularis) di Taman Wisata Alam Grojogan Sewu Tawangmangu Karanganyar," in Seminar Nasional Konservasi dan Pemanfaatan Sumber Daya Alam, 184-187 (2015)

12 H. Alikodra, Pengelolaan Satwa Liar, Jilid I. (Bogor: Fakultas Kehutanan IPB, 1990)

13 A. Kurniawan, "Serangan Awal Kera Ekor Panjang (Macaca fascicularis) pada HTI Acacia mangium di PT. Musi Hutan Persada Sumatera Selatan," Tekno Hutan Tanam., 2, 2, 77-82 (2009)

14 M. D. Gumert, F. Agustin, and L. Jones Engel, Eds., Monkeys on The Edge, Ecology ang Management of Long Tailed Macaques and Their Interface With Humans (New York: Cambridge University Press, 2011)

15 A. Mardiah, Rizaldi, and W. Novarino, "Agresi provokasi dan non-provokasi pada Monyet Ekor Panjang (Macaca fascicularis, Raffles 1821) terhadap pengunjung di Kawasan Gunung Meru," J. Biol. Univ. Andalas, 4, 4, 258-263 (2015)

16 H. Alikodra, Dasar-dasar Pembinaan Margasatwa (Bogor: Fakultas Kehutanan IPB, 1990)

17 O. Oriza, T. R. Setyawati, and Riyandi, "Gangguan Monyet Ekor Panjang ( Macaca fascicularis ) Sekitar Pemukiman di Desa Tumuk Manggis dan Desa Tanjung Mekar, Kecamatan Sambas, Kalimantan Barat," J. Protobiont, 8, 1, 27-31 (2019)

18 J. E. Fa, "Visitor-Directed Aggreesion Among The Gibraltar Macaques," Zoo Bilology, 11, 1, 43-52 (1992)

19 R. Saraswat, A. Sinha, and S. Radhakrishna, "A God Becomes a Pest? Human-Rhesus Macaque Interactions in Himachal Pradesh, Northern India,” Eur. J. Wildl. Res., 61, 3, 435-443 (2015)

20 C. M. Hill and A. D. Webber, "Perceptions of Nonhuman Primates in Human-Wildlife Conflict Scenarios," Am. J. Primatol., 72, 10, 919-924 (2010)

21 R. Sakurai, S. K. Jacobson, and G. Ueda, "Public Perceptions of Significant Wildlife in Hyogo, Japan," Hum. Dimens. Wildl., 19, 1, 88-95 (2014)

22 G. R. Regmi, K. A. I. Nekaris, K. Kandel, and V. Nijman, "Crop-raiding Macaques: Predictions, Patterns and Perceptions From Langtang National Park, Nepal,"Endanger. Species Res., 20, 3, 217-226 (2013)

23 S. A. (UGM) Subrata, S. (UGM) Pudyatmoko, S. (UGM) Nurvianto, and S. (UGM) Subeno, Daya Dukung Habitat Monyet Ekor Panjang di Jawa Tengah. 2019.

24 J. L. Hardwick, N. E. C. Priston, T. E. Martin, D. G. Tosh, A. H. Mustari, and K. E. Abernethy, "Community Perceptions of the Crop-Feeding Buton Macaque (Macaca 
ochreata brunnescens): an Ethnoprimatological Study on Buton Island, Sulawesi," Int. J. Primatol., 38, 6, 1102-1119 (2017) 